Torjer A. Olsen

Senter for samiske studier

UiT Norges arktiske universitet

E-post: torjer.olsen@uit.no

Hilde Sollid

Institutt for lcererutdanning og pedagogikk

UiT Norges arktiske universitet

Ase Mette Johansen

Institutt for språk og kultur

UiT Norges arktiske universitet

\title{
Kunnskap om samiske forhold som integrert del av lærerutdanningene
}

\section{Sammendrag}

Skal du bli lærer i Norge, må du kunne ivareta rettighetene til samiske barn og ungdommer, men også opplcering om samiske forhold for alle elever. Dette slår de nasjonale forskriftene om rammeplan for lererutdanningene fast. Hva betyr egentlig dette for larerutdanningene? I denne artikkelen utforsker vi dette spørsmålet ved å se rammeplanens føringer i sammenheng med samiske temaers plass $i$ utdanningssystemet. Innledningsvis presenterer vi det historiske og juridiske grunnlaget for at denne tematikken skal vere integrert $i$ lcererutdanningene. Et riss av kunnskapsstatusen på feltet gir imidlertid et klart inntrykk av at den politiske støtten til samiske interesser har vart og er utfordrende å implementere i skolen generelt og i lcererutdanningene spesielt. I forlengelsen av dette oppsummerer vi hva rammeplanene for lcererutdanningene faktisk sier om samiske tema. Vi peker på en uttalt mainstreamingdimensjon, der planbeskrivelsene gjelder for alle liererstudenter, ikke bare for dem som skal vœre lcerere for samiske elever i samiske skoler. Disse føringene knyttes videre til en refleksjon rundt samiske og urfolksrelaterte temaers plass i et helhetlig utdanningsløp, og vi argumenterer for at både utvikling av interkulturell kompetanse og utdanning i medborgerskap er relevante overordna målsettinger $i$ denne sammenhengen. Avslutningsvis løfter vi fram behovet for et nasjonalt kompetanseløft på veien mot en lcrerutdanning som tar samiske forhold på alvor og samiske perspektiver i bruk.

Nøkkelord: lcererutdanning, rammeplaner, urfolksutdanning, indigenisering, mainstreaming, interkulturell kompetanse 


\begin{abstract}
If you study to become a teacher in Norway, you are obliged to learn to maintain the rights of Sámi children and youth, as well as to provide education on Sámi issues for all pupils. This is expressed in the national regulations for the teacher education programs. What does this mean for teacher education programs? In this article, we explore this issue by examining the implications of the curriculum with regard to the role of Sámi and indigenous issues in the general educational system. We present the historical and legal basis for the integration of this topic in teacher education. However, a brief overview of the status of knowledge in this field shows that the political support of Sámi interests has been, and still is difficult to implement in education in general, and in teacher education in particular. Next, we summarize what the national curriculum for teacher education actually says about Sámi issues. We point to an explicit mainstreaming dimension where the curriculum goals are obligatory for all teacher students, not only for future teachers for Sámi students in Sámi schools. These guidelines are further connected to a reflexive practice around the place of Sámi and indigenous issues in education, and we argue that both the development of intercultural competence and citizenship education are relevant overarching goals in this context. Finally, we propose a national competence strategy on the road towards developing a Norwegian teacher education that takes Sámi issues and perspectives seriously.
\end{abstract}

Keywords: teacher education, curricula, indigenous education, indigenisation, mainstreaming, intercultural competence

\title{
1 Innledning
}

I de nasjonale forskriftene om rammeplaner for lærerutdanningene heter det at samtlige utdanningsløp skal bidra til forståelse for samenes status som urfolk og gi grunnleggende kunnskaper om samiske forhold i Norge i dag. Bakgrunnen for denne tydelige føringa er at utdanningspolitikken retta mot samene her til lands ble radikalt endra i siste halvdel av det 20. århundret. Etter en lang periode med statsdrevet assimileringspolitikk og ignoranse er vi nå inne i en periode med samisk revitalisering som til dels må sees i sammenheng med oppmykinga av den statlige politikken. Som vi skal se, står skole og utdanningspolitikk sentralt i den norske statens tiltak for å bedre situasjonen for samisk språk og samfunn.

Denne artikkelen tar utgangspunkt i spørsmålet om hva det vil si å ha en profesjonsutdanning som skal belyse samiske tema for alle norske lærerstudenter. I fortsettelsen presenterer vi først det historiske og juridiske grunnlaget for at denne tematikken skal være en integrert del av lærerutdanningene, samt en kort oversikt over hva forskninga så langt forteller 
oss om samiske tema i skolen. Videre oppsummerer vi hva rammeplanene for lærerutdanningene sier om samiske tema. Vi avslutter med å reflektere rundt samiske og urfolksrelaterte temaers plass i et helhetlig utdanningsløp - og å argumentere for at det er tid for et nasjonalt kompetanseløft på feltet.

\section{Norsk urfolkspolitikk og skolen: Fra assimilering og ignoranse til inkludering og indigenisering}

Norsk politikk overfor samer og andre minoriteter hadde fra midten av 1800tallet til ca. 1950 som mål å fornorske minoritetsgruppene både språklig og kulturelt (se for eksempel Minde, 2005). I kjølvannet av denne omfattende assimileringsperioden var samenes stilling i det norske samfunnet naturlig nok marginalisert. Alta-saken rundt 1980 skapte en politisk vending for samenes plass og rettigheter i Norge, og samtidig fikk vi en utvikling av samepolitikken og en revitalisering av samisk kultur og identitet. Den norske staten kom etter hvert med innrømmelser overfor samene, og samenes kamp ble i første omgang krona med innføringa av sameparagrafen i Grunnloven i 1988 og åpninga av Sametinget i 1989.

Styrkinga av samenes rettigheter i norsk sammenheng må også forstås i en internasjonal kontekst: Norge har de seneste tiårene markert seg internasjonalt gjennom en progressiv holdning til urfolk og deres rettigheter, først og fremst ved å stille seg bak FNs avgjørelser og å ratifisere ILO-konvensjon nr. 169 i 1990. En viktig side ved ratifiseringa er en formalisering av Norges anerkjennelse av samene som urfolk. Konvensjonen slår fast at urfolk og stammefolk har rett til selvbestemmelse i bestemte geografiske områder, samt at stater ikke har anledning til å handle på tvers av urfolks ønsker og interesser i saker som angår dem som urfolk. Samenes urfolksstatus i Norge innebærer dessuten at samisk kultur og språk har en særlig verdi. I tillegg er statusen en anerkjennelse av at majoritetssamfunnets historiske handlinger i samiske områder representerer en form for kolonialisme. Disse forholdene er knyttet til den viktige internasjonale folkerettslige dimensjonen av urfolksbegrepet.

Skolen har vært og er fremdeles en helt sentral arena for gjennomføringa av statens politikk overfor samene. Institusjonen ble i en tidlig fase et viktig virkemiddel i koloniseringa gjennom misjonsarbeidet og koblinga til kirka. Skoleloven i 1739 gjorde skolegang påbudt, og en viktig begrunnelse var å skulle lære alle å lese - Bibelen. Hundre år senere var skolen det viktigste og mest effektive redskapet for å implementere assimilasjonspolitikken; skoleinstruksen fra 1880, som slår fast at samisk bare var tillatt å bruke i undervisninga når det var ytterst nødvendig, regnes som fornorskingspolitikkens Magna Carta (jf. Dahl, 1957 etter Jensen, 2005, s. 80). Niemi (2017, s. 131-132) beskriver fornorskingspolitikken overfor samer og kvener som å ha en klar målsetning om assimilasjon. I skolesammenheng innebærer 
assimilasjonspolitikken med andre ord at elever med samisk (eller kvensk) som hjemmespråk primært skulle gjennomføre skolegangen sin på norsk, uten særlig støtte fra morsmålet i læringsprosessen. Nasjonal politikk og nasjonale målsetninger til tross, lange avstander og lokale utfordringer førte til variasjoner innafor de samiske samfunnene (Darnell \& Hoem, 1996).

Etter fornorskninga endres skolens oppdrag overfor minoritetene. Olsen (2017; se også Olsen \& Andreassen, 2016) har studert læreplaner og lærebøker og peker på tre ulike strategier i den skolepolitiske handteringa av samiske og urfolksrelaterte tema i denne fasen: Fravcer, den første strategien, preger etterkrigstida. Skolebøker og planverk sier lite og ingenting om samene. Det kom etter hvert opplæring i samisk, men dette var først og fremst lokale tilbud (Darnell \& Hoem, 1996).

Endringa på nasjonalt nivå blir synlig med innføringa av den første nasjonale læreplanen i 1974 (M74). Skolen blir nå i økende grad en formidler av kunnskap om samisk samfunn og historie. M74 representerer sammen med M87, L97 og K06 den andre strategien, som er inkludering. Dette innebærer at samiske tema tas med i planverk og bøker, men på det norske samfunnets premisser. Den første Rammeplanen for barnehagen (Udir, 1995) hører med i dette bildet. Folkenborg (2008, s. 59) framhever hvordan samiske tema har blitt styrka og søkelyset på urfolk tydeligere i denne perioden. Han understreker samtidig at læreplanene for samfunnsfag helt fram til 2000-tallet ikke forutsetter at (de norske) elevene skal ha spesielt omfattende kunnskaper. Olsen (2017) viser at flertallet av lærebøker som brukes i dag i historie og samfunnsfag, både på ungdomstrinnet og i videregående skole, skriver svært lite om samiske og urfolksrelaterte tema. Noen unntak finnes, men de justerer ikke det helhetlige inntrykket nevneverdig.

Den tredje og siste strategien er indigenisering. Med henvisning til FNs erklæring om urfolks rettigheter fra 2007 påpeker Ngai, Bæck \& Paulgaard (2015, s. 78) at begrepet indigenous education har en tosidig betydning: å utdanne urfolk innafor rammene av deres språk og kultur, men også å utdanne alle i urfolkstematikk. Den første betydninga ligger til grunn for de samiske læreplanene L97S og K06S, som spesielt tar sikte på å ta samenes status som urfolk på alvor og gi et samisk opplæringstilbud med utgangspunkt i et samisk ståsted. ${ }^{1}$ Det åpnes med andre ord for læring på samiske premisser og ut fra samiske interesser og begreper. Ikke desto mindre: De samiske læreplanene og læringsmålene gjelder samiske elever spesielt og ikke elever i majoritetsskolen generelt. Den samme ordninga finner vi i Rammeplan for barnehagen (2006). Her er det én plan for norske og én for samiske barnehager. Til gjengjeld er den norske planen eksplisitt på at det er viktig å fundere barnehagens virksomhet i samenes status som urfolk og på implikasjonene dette har (Olsen \& Andreassen, 2016). Dette henger sammen med å utdanne alle i urfolkstematikk, altså den andre betydninga av begrepet indigenous education i Ngai et al. (2015). Mer presist legger vi til grunn at indigeniseringsstrategien skiller seg fra inkludering 
ved å basere de faglige valgene på et samisk ståsted i undervisninga for alle elever i norsk skole (ikke bare for elever som følger samisk læreplan). Denne formen for mainstreaming (altså undervisning av samiske tema til alle elever, jf. Engen, 2014) av indigeniserende perspektiver kan ikke sies å være like eksplisitt i de nasjonale læreplanene for skolen.

Foreløpig er det gjort lite forskning på kunnskap om samiske og urfolksrelaterte tema blant lærere og elever i norsk skole. Samtidig er det ikke spesielt kontroversielt å hevde at kunnskapsnivået er (for) lavt - parentesen impliserer at det finnes en idé om hva som er tilstrekkelig kunnskap. Lile (2011) argumenterer for at Norge fortsatt ikke har oppnådd å følge lovgivninga som følger ILO-konvensjon nr. 169, ettersom elever og lærere i de skolene han har undersøkt, mangler grunnleggende kunnskaper om samiske forhold.

Både L97/L97S og K06/K06S er blitt gjenstand for evalueringsrapporter. Etter L97/L97S skreiv Vuokko Hirvonen og Jan Helge Keskitalo en rekke rapporter der de understreka betydninga av å ha et eget samisk læreplanverk, samtidig som de viste til utfordringer ved implementering av læreplanene (Hirvonen, 2003, 2004; Hirvonen \& Keskitalo, 2004). I forbindelse med K06/K06S skreiv forskere fra Nordlandsforskning en serie rapporter der de særlig fokuserte på retten til opplæring i og undervisning på samisk (Solstad et al., 2009; Solstad et al., 2010; Solstad, Nygaard \& Solstad, 2012; Solstad, Solstad \& Gustavsen, 2011. Se også Gjerpe, 2017).

Med bakgrunn i vektlegginga av samisk i skolen kan vi si at Norges ansvar for samene som urfolk legger viktige premisser av faglig og innholdsmessig art, også for alle lærerutdannere. For det første skal samiske elever få opplæring i og gjennom egen kultur, men også tilbud om undervisning i samisk som førsteeller andrespråk. For det andre anerkjenner Norge at landet er bygd på territoriet til to folkeslag, og dermed bør den norske befolkninga generelt ha grunnleggende kunnskaper om samiske forhold. Til tross for den etter hvert utvetydige støtten til en politikk som ivaretar samenes interesser, er det utfordrende å implementere denne politikken i skolen. De norske lærerutdanningene er intet unntak. To ferske rapporter fra Følgjegruppa for lærarutdanningsreforma $(2013,2015)$ avdekker at lærestedene har problemer med å ivareta opplæring om samiske tema for lærerstudentene sine. I den første av dem kan vi lese følgende:

Institusjonane rapporterer jamt over at dei synes opplæring i samiske tilhøve er viktig for deira institusjon. Likevel syner undersøkinga vår at det er rimeleg tilfeldig og personavhengig om faglærarane i dei ulike faga faktisk legg vekt på dette i undervisinga, og ikkje minst at ein del studentar seier at dei ikkje har vore innom temaet i det heile. (Følgjegruppa for lærarutdanningsreforma, 2013, s. 86.)

I den andre rapporten konkluderer gruppa med at samiske perspektiver er ei uløst utfordring i gjennomføringa av grunnskolelærerreformen (Følgjegruppa for lærarutdanningsreforma, 2015, s. 11). Det ser med andre ord ut til å være en 
vanskelig oppgave for flere lærer- og lektorutdanningsinstitusjoner å følge opp kravene i rammeplanen. Flere læresteder har ikke selv den kompetansen som kreves, eller det kan bli tilfeldig hvem som har faglig ansvar.

Mye tyder altså på at verken læreplaner, lærebøker, undervisningspraksis eller lærerutdanning per i dag gir tilstrekkelige forutsetninger for at elever i den norske skolen skal kunne utvikle disse kunnskapene - med et unntak for rammeplanen for barnehagen. Det er altså ikke samsvar mellom føringene i lovverk og internasjonale konvensjoner og det den norske skolen og lærerutdanningsinstitusjonene gjør. På bakgrunn av det foregående er det klart at både Grunnloven, sameloven og Norges ratifisering av ILO-konvensjon nr. 169 også forplikter lærerutdanningene til å integrere samiske tema. I forlengelsen av dette er det viktig å ha klart for seg hvilke føringer rammeplanene faktisk gir, ettersom ikke bare utdanningenes plikter, men også studentenes rettigheter er formulert her.

\section{Rammeplanene for lærerutdanningene}

Ansvarsfordelinga mellom norsk og samisk lærerutdanning er viktig å avklare. Rammeplanen for allmennlærerutdanninga fra 2003 (Rammeplan ALU, 2003), som regulerte lærerutdanninga for 1.-10. trinn i perioden 2003-2010, risser denne fordelinga opp. Selv om dagens rammeplaner ikke nevner samisk lærerutdanning eksplisitt, må likevel rammeplanen for den norske lærerutdanninga leses $\mathrm{i}$ lys av Forskrift om rammeplan for samiske grunnskolelærerutdanninger for 1.-7. trinn og 5.-10. trinn ved Samisk høgskole (Rammeplan GLU samisk, 2010). Sistnevnte har utdanning av lærere for samiske samfunn som hovedfokus, mens norsk lærerutdanning skal sørge for kunnskap om samiske forhold i befolkninga for øvrig. Samla sett bidrar begge til innsatsen for å styrke og revitalisere samisk språk og kultur i dagens Norge, og slik sett realisere ambisjonene om et helhetlig utdanningsløp basert på indigenisering som prinsipp.

Når vi nå ser nærmere på hva rammeplanene for norske lærerutdanninger sier mer spesifikt, er det hensiktsmessig å gå litt tilbake i tid: Rammeplan ALU 2003 tar opp samiske tema allerede i det første kapittelet, noe som bidrar til å framheve dette perspektivet. Tematikken inngår i en situasjonsbeskrivelse av språklig og kulturelt mangfold i vid forstand; urfolk, nasjonale minoriteter og barn fra språklige minoriteter omtales i sammenheng. Forskrifta sier følgende om forventninger til studentenes kunnskap: "Studentene må bli kjent med urfolks historie, kultur og institusjoner. I vårt land gjelder dette særlig nordsamisk, lulesamisk og sørsamisk språk, kultur og samfunn.” (Rammeplan ALU, 2003, s. 8.).

Videre er samiske tema omtalt i første kapittel også i den forrige rammeplanen for lærerutdanningene for 8.-13. trinn (Rammeplan PPU, 1999, 
pkt. 1.2). Det poengteres at samisk språk og kultur er en viktig del av norsk historie og samtid, og et sentralt mål for opplæring på alle nivåer er derfor å legge til rette for "å ta vare på og vidareutvikle samisk språk, kultur og samfunnsliv". I avsnittet som omhandler samiske tema for "andre elevar”, står det følgende:

Andre elevar skal få innføring i samisk kultur og samfunnsliv som ein del av fedrelandet sin kultur. Samisk språk, kultur, historie og samfunnsliv er ein del av lærestoffet i læreplanar for fag i grunnskolen. Samisk litteratur inngår dessutan i norskfaget for alle elevar i vidaregåande opplæring. (Rammeplan PPU, 1999, s. 11.)

Den sentrale plasseringa av omtalen av samiske tema er videreført i gjeldende rammeplaner for henholdsvis grunnskolelærerutdanningene og lektorutdanninga 8.-13. trinn. Nærmere bestemt møter vi denne omtalen i delene om virkeområde og formål, noe som understreker at vi har å gjøre med et viktig premiss i norske lærerutdanninger: ${ }^{2}$

Grunnskolelærerutdanningene skal kvalifisere kandidatene til å ivareta opplæring om samiske forhold og ha kunnskap om samiske barns rett til opplæring i tråd med opplæringsloven og gjeldende læreplanverk for grunnopplæringen. (Rammeplan GLU, 2010, §1)

Lektorutdanning for trinn 8-13 skal kvalifisere kandidatene til å ivareta opplæring om samiske forhold, herunder kjennskap til den statusen urfolk har internasjonalt, og samiske barn og ungdoms rett til opplæring i tråd med opplæringsloven og gjeldende læreplanverk. (Rammeplan lektor, 2013, §1)

Det vil føre for langt å gå inn på en mer detaljert analyse av ordlyden i de fire omtalte rammeplanene, men på et overordna nivå ser vi at rammeplanene blir harmonisert i overgangen til dagens forskrifter, slik at formuleringene er forholdsvis like. ${ }^{3}$

Dagens rammeplaner gir imidlertid ikke veldig presise føringer for mulige tilnærminger til samiske tema i lærerutdanningene. Særlig når det gjelder formuleringa "opplæring om samiske forhold" er det langt på vei opp til institusjonene å gjøre prioriteringer. De står likevel ikke fritt til å handtere dette helt som de vil, for formålene må leses i lys av at de tre utdanningsprogrammene som beskrives i de to forskriftene, skal være profesjonsretta. Lærerutdanningene må med andre ord ta hensyn til føringene både i programmenes primære skolenivåer (1-7, 5-10 eller 8-13) og - ikke minst - i gjeldende læreplanverk, K06.

På to punkter er likevel rammeplanene svært tydelige: Lærerutdanningene skal bidra til at nye lærere ivaretar samiske barns og ungdommers rettigheter til opplæring i og på samisk og om samiske tema. Lærernes juridiske ansvar på dette området er med andre ord entydig: Lærerstudentene skal forberedes til å kunne fortolke og forvalte lovverket på best mulig måte i den aktuelle 
situasjonen og for elevgruppa som læreren har ansvar for. Opplæringsloven og gjeldende læreplanverk nevnes spesielt. I tillegg er samiske barns rettigheter beskytta av sameloven mer generelt. I forlengelsen av dette er det grunn til å se lærerens kunnskap om samiske elevers rettigheter i forbindelse med den helhetlige organisatoriske og pedagogiske tilrettelegginga som de i neste omgang skal foreta for denne elevgruppa. Hermansen og Olsens (2012) analyse av foreldres erfaringer med valg av samiskopplæring for barn utenfor det samiske forvaltningsområdet, kan tjene som et eksempel. De viser blant anna hvordan mødre opplever ansvar og risiko rundt dette private språkvalget, som utvilsomt får store konsekvenser for barna. I en slik sammenheng spiller læreren og skolen en uvurderlig rolle i å tilrettelegge opplæringa til det beste for barnet.

Videre har rammeplanene for lærerutdanningene det vi vil beskrive som en uttalt mainstreamingdimensjon. Beskrivelsene gjelder for alle lærerstudenter, ikke bare for dem som skal være lærere for samiske elever i samiske skoler. Føringene om kunnskaper om samiske forhold blir gitt til alle som skal bli lærere.

\section{Med interkulturell kompetanse som mål}

Et viktig og ofte brukt begrep når det norske samfunnet blir beskrevet, er flerkultur. Samtidig er det slik at flerkulturbegrepet tenderer til ikke å omfatte samene og de nasjonale minoritetene (Andreassen \& Olsen, 2014, s. 11), men først og fremst de siste tiårs innvandrere til Norge, og kanskje aller mest muslimer. Samtidig er det viktig å huske på at Norge har hatt flere kulturer representert lenge før arbeidsinnvandringa virkelig tok til på 1970-tallet. I store områder har innslag fra ulike deler av det samiske samfunnet en mye eldre historie enn nasjonalstaten Norge. Dermed vil vi ha som utgangspunkt at flerkultur er et begrep som beskriver det norske samfunnet over flere århundrer.

Et lite sideblikk til barnehagen, som tilhører det helhetlige utdanningsløpet, illustrerer utviklinga hva angår flerkultur og samenes plass i utdanningssystemet. I den første rammeplanen for barnehagen som kom i 1995, ble det norske samfunnet omtalt som å være i en ny tilstand av flerkultur. Samene ble beskrevet som å ha en særlig kompetanse og et særlig ansvar for å bidra til andre minoriteters situasjon og integrasjon. I den neste og gjeldende planen fra 2006 er dette merkverdige punktet fjerna, og samene som urfolk blir satt inn i den større flerkulturelle sammenhengen i Norge (Olsen \& Andreassen, 2016).

Tidligere i denne artikkelen har vi brukt formuleringa at lærerutdanningene og skolen skal "gi grunnleggende kunnskaper om samiske forhold", uten å drøfte den nærmere. Målsettinga kan umiddelbart se ut til å handle om å utvikle kunnskap om samer og urfolk; et vi (de norske) må lære om dem (de samiske). 
Læreplanverket for kunnskapsløftet retter oppmerksomheta vår mot et overordna mål i skolen som er langt mindre essensialiserende og tilsvarende mer ambisiøst:

For å utvikle elevane sin kulturelle kompetanse til å delta i eit multikulturelt samfunn skal opplæringa leggje til rette for at dei får kunnskap om ulike kulturar og erfaring med eit breitt spekter av kulturelle uttrykksformer. Opplæringa skal fremme kulturforståing og medverke til å utvikle både sjølvinnsikt og identitet, respekt og toleranse. (Læreplanverket for Kunnskapsløftet, 2006, s. 3.)

Med utgangspunkt i dette sitatet definerer Østberg (2017) interkulturell kompetanse som "en handlingskompetanse som er basert på kunnskap om og innsikt i mangfold generelt og kulturelt mangfold spesielt” (s. 19). Videre understreker hun at interkulturell i større grad enn flerkulturell vektlegger mellommenneskelig samhandling framfor forståelse av de enkelte gruppene i seg selv. I en mer omfattende framstilling utdyper Barrett, Byram, Lázár, Mompoint-Gaillard \& Philippou (2014, s. 16) begrepet, og argumenterer for at interkulturell kompetanse kan forstås som en kombinasjon av holdninger, forståelse, kunnskap og ferdigheter som aktiviseres og anvendes i møter mellom mennesker. Ser vi målsettinga i sitatet fra Kunnskapsløftet og begrepet interkulturell kompetanse i sammenheng, handler det i utdanningskontekster om å legge til rette for at elever og studenter rustes til å reflektere åpent og respektfullt over likheter og forskjeller i det mellommenneskelige møtet. På bakgrunn av dette må lærerstudentene gjennom utdanninga bli invitert til å bygge kunnskap om og reflektere over språklig og kulturelt mangfold som en felles erfaring i det moderne norske samfunnet de er en del av.

Moderne mønstre for mellommenneskelig samhandling gjør slik kunnskap og refleksjon relevant også på et globalt nivå. Ngai et al. (2015, s. 103-104) framhever eksempelvis hvordan transnasjonale og interkulturelle forbindelser i vår tid åpner opp for at unge mennesker i økende grad føler tilhørighet til et vell av sosiokulturelle kontekster. Urfolkstematikk kan, som en integrert del av opplæringa, bidra til utdanning i medborgerskap, (citizenship education) (Ngai et al., 2015) i en global kontekst. Noen av de store verdensomspennende utfordringene vi står overfor - eksempelvis global oppvarming og klimaendringer, økende rasisme og trusselen mot biokulturelt mangfold fordrer for det første samarbeid på tvers av etablerte historiske og nasjonale skillelinjer. For det andre er urfolksperspektiver sentrale for å forstå hva disse utfordringene innebærer.

Og på samme måte som elever og studenter utfordres til å se sitt eget ståsted, er det av stor betydning med refleksjon rundt institusjonens og forskerens/fortellerens ståsted i møte med samiske forhold. Som forskere er vi nødt til å forholde oss til en historie der forskninga, universitetet som institusjon og skolesystemet i all hovedsak har vært en del av koloniseringsapparatet. Smith sier det ganske så krast i boka Decolonizing Methodologies. Research and Indigenous Peoples, som er blitt et standardverk innafor urfolksforskning: "The 
word itself, 'research', is probably one of the dirtiest words in the indigenous world's vocabulary" (Smith, 2010, s. 1).

I utviklinga av undervisningspraksis som skal svare på utfordringene i læreplanene, har refleksjonen rundt perspektiv og ståsted flere dimensjoner. Det perspektivet vi anlegger i formidlinga, avspeiler et ståsted, enten vi vil det eller ikke. Ettersom det ikke finnes et nøytralt ståsted, blir vi som lærere på et eller anna vis nødt til å ta stilling. Smith (2010) kommer med en rekke krav til forskning på urfolksrelaterte forhold. Disse kravene kan overføres til undervisning om samme tematikk: "Whose interests does it serve? Who will benefit from it? Who has designed its questions and framed its scope?" (Smith, 2010, s. 10). For oss som lærerutdannere kan disse spørsmålene fungere som en kritisk rettesnor.

Vårt utgangspunkt er at vår virksomhet skal støtte målene i de norske lærerutdanningene og samtidig være sensitiv overfor samiske perspektiver. Målsettinga er at såkalt mainstreaming (Engen, 2014, s. 83) av kunnskap om samiske tema til hele den norske studentgruppa skal være inspirert av indigenisering, jf. Olsens (2017) nevnte tredje strategi i planverk og lærebøker. Dette innebærer å utvikle en reflektert holdning både til hva som formidles om samiske forhold, og til hvordan formidlingen skjer. Med indigenisering som mål bør lærere etterstrebe å gjenkjenne og skjønne samiske perspektiver, samt å unngå ulike varianter av andregjøring eller "vi og de andre"-tenkning. Ambisjonen om å utøve interkulturell kompetanse i arbeidet med utforming og presentasjon av ulike tema, forutsetter kontinuerlig og eksplisitt refleksjon. På denne måten kan vår refleksjon ha en pedagogisk dimensjon, og studentene kan selv oppfordres til å reflektere rundt eget ståsted.

En problematisk side ved mainstreaming ligger i faren for at undervisningen kan tilsvare det som i Aotearoa/New Zealand er kalt whitestreaming. I en utdanningskontekst innebærer dette at læreplaner, lærebøker og/eller undervisning sees som å være utforma og iverksatt på det hvite majoritetssamfunnets premisser (Ritchie \& Skerrett, 2014, s. 51). Slik vi ser det, er det i første omgang nesten uunngåelig at noe tilsvarende skjer i Norge. Samtidig er pågående refleksjon og kritisk kunnskapspåfyll nødvendig for å motvirke whitestreaming.

\section{Samiske og urfolksrelaterte tema i et helhetlig utdanningsløp}

Gjennomgripende tendenser for behandlinga av samiske og urfolksrelaterte tema i norsk skolepolitikk er inkludering og indigenisering. En anna overordna tendens i skole- og utdanningspolitikken er utviklinga mot et helhetlig utdanningsløp. Barnehagene har fått rammeplaner og er blitt starten av et løp der ikke bare grunnskolen og videregående utdanning er inkludert; også høyere utdanning er en del av det samme løpet. Et helhetlig blikk på samiske og 
urfolksrelaterte tema i de nyeste planverkene for hele utdanningsløpet viser at det for en stor del er likelydende formuleringer som gjelder. Her er det definitivt rom for forskning som går dypere inn i sammenhengen, men tendensene er klare.

En følge av dette er at det ligger godt til rette for en profesjonsnær lærerutdanning, der kunnskap om samiske tema både er en del av formålet med utdanninga og en del av det faglige innholdet som lærerstudentene skal ivareta i utøvelsen av yrket. Lærerutdanningene skal dermed gi studentene kunnskaper om samiske forhold som de kan videreformidle gjennom egen praksis som et ledd i utvikling av interkulturell kompetanse. Dette gjelder i uansett hvilken del av det helhetlige utdanningsløpet de skal arbeide.

Vi ser dette helhetlige løpet som et gunstig utgangspunkt for bedre handtering av forpliktelsene fra ILO-konvensjon nr. 169. At elever og studenter skal møtes av noenlunde like krav til kunnskaper om samiske tema, uavhengig av hvilket nivå de er på, skaper forutsigbarhet og felles referanserammer.

Det ligger imidlertid et sett av spenninger i de ambisiøse formuleringene. Et dilemma er knytta til forholdet mellom lokale og nasjonale muligheter og begrensninger. Så langt har praksisen i stor grad vært at det først og fremst er noen av lærerutdanningene som har tatt særlig ansvar for samiske og urfolksrelaterte tema i undervisninga si. Dette kan kanskje forsvares ut fra at det fortrinnsvis er i områder som disse utdanningene rekrutterer studenter fra, at man finner samisk bosetning. Med de nye formuleringene i planverket er det likevel slik at en argumentasjon av denne typen ikke holder. Uansett hvor du tar lærerutdanningen din, skal du få kunnskap om samiske og urfolksrelaterte tema. Dette burde imidlertid ikke forhindre lokal variasjon og/eller fordypning. Her kan nettopp lokale kontekster bidra til å avgjøre hvor fordypninga kan gjøres.

\section{Tid for et nasjonalt kompetanseløft}

Det har etter hvert blitt vanlig med målretta, nasjonale kompetanseløft på områder som representerer store utfordringer i norsk skole. Eksempler av nyere dato er "Ungdomstrinn i utvikling” og "Kompetanse for mangfold”, og lærere tilbys i dag tilpassa etter- og videreutdanning, for eksempel i realfag. Flere læresteder har ulike kurs i samisk kulturkunnskap, men har slitt med få søkere. Disse kursene har nok ikke blitt brukt som ressurs for å oppfylle kravene i rammeplanen, men er antakelig oppfatta som et tilbud for eksempelvis historieeller samfunnsfaglærere.

I en situasjon der planverket stiller nye krav, er det maktpåliggende med nyvinninger. Det er behov for flere undervisningsressurser og for å tenke nytt om hvordan undervisninga organiseres. UiT Norges arktiske universitet har siden 2002 hatt et nasjonalt ansvar for samisk og urfolksrelatert forskning, utdanning og formidling. Ansvaret er nedfelt i plandokumenter på alle nivåer 
ved institusjonen, inkludert i strategiplanen for Fakultet for humaniora, samfunnsvitenskap og lærerutdanning. UiT er likevel ikke alene om å ha og ta ansvar for samiske og urfolksrelaterte tema. Samisk høgskole har et nasjonalt ansvar for samisk lærerutdanning, men også for områdene duodji og nordsamisk språk. Nord universitetet har et særskilt ansvar for lule- og sørsamisk. Når det er sagt, velger vi å tolke kombinasjonen av nyvinningene i rammeplanene for lærerutdanningene, samt UiTs ansvar på feltet, som en unik mulighet til å kunne bidra nasjonalt.

Som en konsekvens av dette har fakultetet, i samarbeid med ProTed, (Professional Learning in Teacher Education, Senter for fremragende utdanning (SFU) ved UiT og Universitetet i Oslo) tatt initiativ til et prosjekt for å bidra til et tverrfaglig kompetanseløft i lærerutdanningene om samene som urfolk og minoritet. Mer spesifikt utvikles det nå en pilotressurs for en nettbasert læring, Reaidu ${ }^{4}$, som skal styrke lærerstudentenes kunnskap om samisk språk, kultur, samfunn og politikk, men også invitere til refleksjon rundt disse temaene og relevansen av dem i praksisfeltet, blant anna i tilknytning til samiske barn og unges rettigheter.

Prosjektet om et tverrfaglig kompetanseløft om samisk i lærerutdanningene har et lokalt utgangspunkt, men et nasjonalt siktemål: En nettressurs har potensial til å bli et læringsverktøy for lærerstudenter over hele landet. Det er utfordringer forbundet med slike nettbaserte læringsressurser, blant anna knytta til langsiktige forpliktelser om faglig og teknologisk vedlikehold og til spørsmål om hvordan lærerstudentene faktisk vil bruke nettressursen. Samtidig er det en erkjennelse at kompetansen knytta til samisk og urfolksrelatert forskning, utdanning og formidling er fordelt på et fåtall av landets lærerutdanninger. Skal de overordna målene i rammeplanene for lærerutdanningene implementeres, kreves det et faglig oppdatert, profesjonsorientert og samtidig effektivt system for å nå så mange lærerstudenter som mulig.

Vårt utgangspunkt er at som lærer i Norge, har du et dobbelt oppdrag. Som vi har vist, blir dette slått fast i de nasjonale forskriftene om rammeplan for lærerutdanningene. Du må kunne ivareta rettighetene til samiske barn og ungdommer, men også opplæring om samiske forhold for alle elever. Som lærer i skolen skal du bidra til å utvikle medborgere med kulturell kompetanse og forståelse, noe som på den ene sida innebærer å legge til rette for å utvikle generell kunnskap om samiske samfunnsforhold og historie uavhengig av hvor i Norge skolen er. Dette definerer vi i denne sammenhengen som mainstreaming. Dette doble oppdraget må reflekteres i lærerutdanningenes praksis. Å se de to oppdragene i sammenheng kan være et steg på veien mot en profesjonsutdanning som tar samiske forhold på alvor og samiske perspektiver i bruk. 


\section{Referanser}

Andreassen, B.O. \& Olsen, T.A. (2014). Religion, etikk og filosofi i barnehagen. Oslo: Universitetsforlaget.

Barret, M., Byram, M., Lázár, I., Mompoint-Gaillard, P. \& Philippou, S. (2014). Developing Intercultural Competence through Education. (Council of Europe Pestalozzi series No. 3). Council of Europe: Council of Europe Publishing.

Dahl, H. (1957). Skolepolitikk og skolestell i Finnmark 1814-1905. Oslo: Universitetsforlaget.

Darnell, F. \& Hoem, A. (1996). Taken to the Extremes. Education in the Far North. Oslo: Scandinavian University Press.

Engen, T.O. (2014). Tilpasset opplæring i superdiversiteten. I K. Westrheim \& A. Tolo (red.), Kompetanse for mangfold. Om skolens utfordringer i det flerkulturelle Norge (s. 56-95). Bergen: Fagbokforlaget.

Folkenborg, H.R. (2008). Nasjonal identitetsskaping i skolen. En regional og etnisk problematisering. Tromsø: Eureka.

Følgjegruppa for lærarutdanningsreforma (2013). Drivkraft i utviklinga av lierarprofesjonen? Framsteg og utfordringar for grunnskulelærarutdanningane. (Rapport nr. 3 frå Følgjegruppa til Kunnskapsdepartementet). Stavanger: Følgjegruppa for lærarutdanningsreforma.

Følgjegruppa for lærarutdanningsreforma (2015). Grunnskolelærarutdanningane etter fem år. Status, utfordringar og vegar vidare (Rapport nr. 5 frå Følgjegruppa til Kunnskapsdepartementet). Stavanger: Følgjegruppa for lærarutdanningsreforma.

Gjerpe, K.K. (2017). Samisk læreplanverk - en symbolsk forpliktelse? Nordic Studies in Education. (kommer)

Hermansen, N. \& Olsen, K. (2012). Valg, ansvar, risiko og etnisk identitet i en finnmarksk modernitet. Norsk Pedagogisk Tidsskrift, 3, 210-222.

Hirvonen, V. (2003). Sámi skuvla plánain ja praktihkas: Mo dustet O97S hástalusaid?: reforma 97 evalueren. Guovdageaidnu: Sámi allaskuvla.

Hirvonen, V. (Red.) (2004). Samisk skole i plan og praksis: hvordan møte utfordingene i L97S?: evaluering av Reform 97. Kárášjohka: Sámi allaskuvla.

Hirvonen, V., \& Keskitalo, J. H. (2004). Samisk skole - en ufullendt symfoni? I T. O. Engen \& K. J. Solstad (red.), En likeverdig skole for alle? om enhet og mangfold i grunnskolen (s. 200-219). Oslo: Universitetsforlaget.

Jensen, E.B. (2005). Skoleverket og de tre stammers møte. Tromsø: Eureka.

Lile, H.K. (2011). FNs barnekonvensjon artikkel 29 (1) om formålet med opplcring: En rettssosiologisk studie om hva barn lerer om det samiske folk. (Doktoravhandling), Universitetet i Oslo, Oslo.

Læreplanverket for Kunnskapsløftet (2006). Prinsipper for opplæringa. Henta fra https://www.udir.no/globalassets/upload/larerplaner/fastsatte_lareplaner_for_kunnskapslo eftet/prinspipper_lk06_nn.pdf

Minde, H. (2005). Fornorsking av samene - hvorfor, hvordan og hvilke følger? Henta fra http://skuvla.info/skolehist/minde-n.htm

Ngai, P., Bæ[c]k, U.D.K., \& Paulgaard. G. (2015). Indigenous Education in the Norwegian and U.S. Contexts. I K.W. Shanley \& B. Evjen (red.), Mapping Indigenous Presence. North American Perspectives, (s. 78-119), Tucson: The University of Arizona Press.

Niemi, E. (2017). Fornorskningspolitikken overfor samene og kvenene. I N. Brandal, C.A. Døving \& I.T. Plesner (red.), Nasjonale minoriteter og urfolk i norsk politikk fra 1900 til 2016. Oslo: Cappelen Damm Akademisk. 
Olsen, T.A. (2017). Colonial Conflicts: Absence, Inclusion, and Indigenization in Textbook Presentations of Indigenous Peoples. I J. Lewis, B-O. Andreassen \& S.A. Thobro (red.). Textbook Violence (71-86). Sheffield: Equinox. (I trykking).

Olsen, T.A. \& Andreassen, B.O. (2016). Ansvar, hensyn og forpliktelse. Urfolk og samiske forhold i barnehagens rammeplaner. I N. Askeland \& B. Aamotsbakken (red.), Folk uten land. A gi stemme og status til urfolk og nasjonale minoriteter, (s. 60-76). Kristiansand: Portal.

M74 = Mønsterplan for grunnskolen 1974.

M87 = Mønsterplan for grunnskolen 1987.

Rammeplan ALU (2003). = Rammeplan for allmennlæererutdanningen 2003. Henta fra: https://www.regjeringen.no/globalassets/upload/kd/vedlegg/uh/rammeplaner/larer/ramme planalu2009.pdf

Rammeplan for barnehagen (1995). Utdanningsdirektoratet: Oslo.

Rammeplan for barnehagen (2006/2011). Henta fra http://www.udir.no/laring-ogtrivsel/rammeplan/barnehagens-innhold/rammeplan-for-barnehagens-innhold-ogoppgaver/

Rammeplan GLU (2010). = Forskrift om rammeplan for grunnskolelærerutdanningene 1.-7. og 5.-10. trinn. Henta fra: https://www.regjeringen.no/no/dokumenter/forskrift-omrammeplan-for-grunnskolelar/id594357/

Rammeplan GLU samisk (2010). = Forskrift om rammeplan for de samiske grunnskolelærerutdanninger fr 1.-7. og 5.-10. trinn ved Samisk høgskole. Henta fra: https://www.regjeringen.no/contentassets/f5524faaec414532977ca8ab94e402d2/forskrift rammeplan_samiske_grunnskolelaererutdanninger_norskversjon.pdf

Rammeplan GLU 1-7 (2016). = Forskrift om rammeplan for grunnskolelærerutdanning for trinn 1-7. Henta fra:

https://www.regjeringen.no/contentassets/fbaf26939bbd40abacba73e34a95d2fc/forskriftom-rammeplan-for-grunnskolelarerutdanning-for-trinn-1-7.pdf

Rammeplan GLU 5-10 (2016). = Forskrift om rammeplan for grunnskolelærerutdanning for trinn 5-10. Henta fra:

https://www.regjeringen.no/contentassets/fbaf26939bbd40abacba73e34a95d2fc/forskriftom-rammeplan-for-grunnskolelarerutdanning-for-trinn-5-10.pdf

Rammeplan lektor (2013). = Forskrift om rammeplan for lektorutdanning for 8.-13. trinn. Henta fra:

https://www.regjeringen.no/globalassets/upload/kd/vedlegg/rammeplanen/lektorutdanning .pdf

Rammeplan PPU (1999). = Rammeplan og forskrift for praktisk pedagogisk utdanning. Henta fra:

https://www.regjeringen.no/globalassets/upload/kilde/kd/pla/2006/0002/ddd/pdfv/175796 -2rammeplan_2003_ppu.pdf

Ritchie, J. \& Skerrett, M. (2014). Early Childhood Education in Aotearoa New Zealand. History, Pedagogy and Liberation. New York: Palgrave Pivot.

Smith, L. T. (2010). Decolonizing Methodologies. Research and Indigenous Peoples. London/New York: Zed Books.

Solstad, K. J., Bongo, M. A., Eriksen, L., Germeten, S., Kramvig, B., Lyngsnes, K. \& Nygaard, V. (2009). Samisk opplering under LK06-samisk: analyse av læereplan og tidlige tiltak for implementering (Vol. 3/2009). Bodø: Nordlandsforskning.

Solstad, K. J., Bongo, M. A., Eriksen, L., Germeten, S., Lyngsnes, K. \& Solstad, M. (2010). Fra plan til praksis: erfaringer med Kunnskapsløftet samisk (LK06S) (Vol. 6/2010). Bodø: Nordlandsforskning. 
Solstad, K. J., Nygaard, V. \& Solstad, M. (2012). Kunnskapsløftet 2006 Samisk: mot en likeverdig skole?: sluttrapport fra evalueringsarbeidet av Kunnskapsløftet Samisk (LK06S) (Vol. 1/2012). Bodø: Nordlandsforskning.

Solstad, K. J., Solstad, M., \& Gustavsen, A. (2011). Rett til samisk opplering - ideal eller realitet (Vol. 3/2011). Bodø: Nordlandsforskning.

Østberg, S. (2017). Interkulturell kompetanse. I V. Bjarnø, M.E. Nergård \& F. Aarsæther (Red.). Språklig mangfold og læring. Didaktikk for flerspråklige klasserom, (s. 17-35). 2. utgave. Oslo: Gyldendal.

\footnotetext{
${ }^{1}$ I 1997 ble det for første gang presentert en egen samisk læreplan til bruk i kommuner og skoler i det samiske språkforvaltningsområdet, L97S. Dette representerer et skifte som videreføres i K06S. Formuleringer og grunnideer i det samiske planverket gjenspeiles i læreplaner/rammeplaner for både barnehage, grunnskole, videregående skole og høyere utdanning.

${ }^{2}$ Selv om denne lærerutdanningsreformen introduserte en differensiering mellom GLU 1.-7. og 5.-10. trinn, har løpene felles rammeplan.

${ }^{3}$ I de nye forskriftene for grunnskolelærerutdanningene som trer kraft fra 2017, ser vi at formuleringene i begge forskriftene er videreført, jf. Rammeplan GLU 1-7 (2016), og Rammeplan GLU 5-10 (2016).

${ }^{4}$ Nettstedet Reaidu finnes på følgende adresse: http://result.uit.no/reaidu/
} 